\title{
Social Support and Community Integration in Users of Brazil's Basic Social Protection Policy
}

\section{Apoyo Social e Integración Comunitaria en los Usuarios de la Política Brasileña de Protección Social Básica}

\author{
Adolfo Pizzinato ${ }^{1}$, Damião Soares de Almeida-Segundoㄹ, Esequiel Pagnussat2, ${ }^{1}$, \\ João Luis Almeida Weber ${ }^{4}$, and Katia Bones Rocha ${ }^{5}$ \\ ${ }^{1}$ Programa de Pós-Graduação em Psicologia, Universidade Federal do Rio Grande do Sul \\ ${ }^{2}$ Curso de Psicologia, Faculdade Católica do Rio Grande do Norte \\ ${ }^{3}$ Curso de Psicologia, Universidade Potiguar \\ ${ }^{4}$ Curso de Psicologia, Centro Universitário da Serra Gaúcha \\ ${ }_{5}^{5}$ Programa de Pós-Graduação em Psicologia, Pontifícia Universidade Católica do Rio Grande do Sul
}

\begin{abstract}
This study aimed to verify how community participation, family support, and sociodemographic variables relate to community integration. Participants were 201 individuals from the Brazilian state of Rio Grande do Sul, residing in the cities of Porto Alegre and Esteio, who benefited from a basic social protection program, PAIF (Proteção e Atendimento Integral à Família). The non-probability sample was mainly composed of low socioeconomic status women with a low educational level who were beneficiaries of social financial support programs. The research protocol comprised the Inventory of Family Support Perception, the Questionnaire of Community Social Support, and questions about sociodemographic characteristics. Correlation of PAIF participation duration with community integration was weak $(r=0.145, p<0.05)$. A linear regression model showed that age $(B=0.323, p<0.001)$, the monetary value of the benefit $(B=0.224, p=0.002)$, and community participation $(B=0.234, p=0.002)$ were predictors, accounting for $30.5 \%$ of the variance of community integration. Results indicate that, as people age in the community, they increase their integration. The amounts received by each family probably affect community integration because they expand access to community spaces and public services. Individuals with greater community support tools felt more welcome in the community network. Additional studies are needed to provide evidence for the effectiveness of social integration and health promotion interventions.
\end{abstract}

Keywords: social support, community integration, social care policies, Brazil

Este estudio tuvo como objetivo verificar la asociación de la participación comunitaria, el apoyo familiar y las variables sociodemográficas con la integración comunitaria. Los participantes fueron 201 personas del estado brasileño de Rio Grande do Sul, residentes en las ciudades de Porto Alegre y Esteio, asistidos por un programa de protección social básica, PAIF (Proteção e Atendimento Integral à Família). La muestra fue no probabilística, compuesta principalmente por mujeres de baja condición socioeconómica, bajo nivel educativo y beneficiarias de programas sociales de apoyo financiero. El protocolo de la encuesta incluía el Inventario de Percepción de Apoyo Familiar, el Cuestionario de Apoyo Social Comunitario y preguntas sobre características sociodemográficas. La correlación de la duración de la participación de PAIF con la integración comunitaria fue débil $(r=0,145, p<0,05)$. Los predictores en el modelo de regresión lineal fueron la edad $(B=0,323, p<0,001)$, el valor del beneficio $(B=0,224$, $p=0,002)$ y la participación comunitaria $(B=0,234, p=0,002)$, los cuales representaron el $30,5 \%$ de la variación en la integración comunitaria. Los resultados indican que, a medida que las personas envejecen en la comunidad, aumentan su integración. Probablemente los valores de beneficio recibidos afectan la integración porque amplían el acceso a los espacios comunitarios y a los servicios públicos. Las personas con mayores herramientas de apoyo se

Adolfo Pizzinato (iD https://orcid.org/0000-0002-1777-5860

Damião Soares de Almeida-Segundo (D) https://orcid.org/0000-0003-2407-0583

Esequiel Pagnussat iD https://orcid.org/0000-0001-9677-434X

João Luis Almeida Weber (D) https://orcid.org/0000-0002-7434-2359

Katia Bones Rocha iD https://orcid.org/0000-0001-7603-1709

This study received economic support from the Ministério do Desenvolvimento Social e do Conselho Nacional de Pesquisa (CNPq), Brazil, through the 457012/2013-7 project.

Correspondence concerning this article should be addressed to Adolfo Pizzinato, Programa de Pós-Graduação em Psicologia Social e Institucional, Universidade Federal do Rio Grande do Sul, Rua Ramiro Barcelos N ${ }^{\circ}$ 2600, Porto Alegre, Rio Grande do Sul, Brazil. Email: adolfopizzinato@hotmail.com 
sienten más acogidas en la red comunitaria. Se necesitan estudios adicionales para aportar pruebas sobre la efectividad de intervenciones para la integración social y la promoción de la salud.

Palabras clave: apoyo social, integración comunitaria, políticas de asistencia social, Brasil

\section{Brazilian Social Care Policy}

In Brazil, a model of public policy oriented toward a welfare state has only recently been built. The concept of social security, present in the Brazilian Constitution of 1988, marks a departure from a model based on policies of stratified social protection aimed at formal workers to a model of equity and universality in the spheres of social security, health, and social care (Jaccoud et al., 2010). However, only after the year 2004, through the approval of the National Social Care Policy (PNAS), the Unified System of Social Assistance (SUAS) was implemented and regulated, with the goal of breaking with the assistentialist, clientelist, and charitable logic historically associated with social assistance in Brazil (Secretaria Nacional de Assistência Social [SNAS], 2005).

Currently, SUAS's hierarchy is divided into two levels: special social protection, whose goal is to monitor at-risk populations when their rights are infringed upon (e.g., abandonment, sexual abuse, destitution, homelessness), and basic social protection, whose function is to prevent the worsening of situations of social vulnerability (SNAS, 2005). People are categorized as socially vulnerable when they lack material or psychological resources to formulate strategies that might enable them to reach acceptable levels of social security (Janczura, 2012). According to the PNAS, the main circumstances that expose certain groups to social vulnerability are conditions of poverty, difficulty in accessing basic services and property, family violence, poor or non-existent participation in the job market, and the weakening of family and community networks (SNAS, 2005).

In this context, Brazilian authorities created Proteção e Atendimento Integral à Família (PAIF), the main service within the basic social protection system. This program monitors families in situations of social vulnerability, aiming to safeguard and strengthen ties among family, community, and institutional networks (e.g., education, health, and social assistance) while also supporting community integration, promoting autonomy, creating income, and providing social vigilance. This service is offered in Centers of Reference for Social Assistance (CRAS), public state units found in socially vulnerable areas (SNAS, 2005).

There are currently 8,155 CRAS in Brazil that reach 1,654,210 families through the PAIF service (SNAS, 2016). CRAS also monitor families in the Programa Bolsa Família (PBF), a conditional income transfer program benefiting families living in poverty (monthly income per person ranging from $\mathrm{R} \$ 85.01$ to $\mathrm{R} \$ 170.00$ or from US\$ 26.11 to US $\$ 52.21$ ) or extreme poverty (monthly income per person up to R $\$ 85.00$ or US $\$ 26.10$; all values converted from the average dollar exchange rate in September 2016-US\$ 3.256-), including pregnant women, breastfeeding mothers, and children or teenagers from 0 to 17 years old (Caixa Econômica Federal, n.d.). Families benefiting from this program are monitored by the public health and education services. Monitoring consists of vaccination according to the Brazilian immunization program, periodic health and growth evaluations, a school attendance rate of at least $85 \%$ or $70 \%$, depending on the child's age, and prenatal, postnatal, and nutritional education for pregnant and lactating women (Rasella et al., 2013; Mourão \& de Jesus, 2011).

\section{Social Support and Community Integration}

The community is the smallest unit in which CRAS is present. It is defined by geographical and institutional delimitations, as well as by cultural traditions (Stumbo et al., 2015). The overarching principle of Brazilian social assistance, which guides other objectives, is the strengthening of family and community bonds (Departamento de Proteção Social Básica, 2017; SNAS, 2012). Thus, it aims to promote the establishment of social support networks to deal with problems and mobilize resources and skills at the individual, family, and community level. A community network, along with a family network, is part of an individual's social network. The community network comprises informal systems (e.g., churches, sport associations, clubs, neighbors, non-governmental organizations-NGOs-) and formal systems (e.g., health units, social and mental health assistance, schools; Gracia Fuster et al., 2002).

Community integration and participation, as dimensions of social support, are decisive for the establishment, maintenance, and strengthening of the individual's social network (Gracia Fuster et al., 2002). 
Integration refers to appreciation for the community and the feeling that one belongs to it, while participation is the individual's degree of engagement in social life and matters related to the community network. Community integration allows individuals to feel that they are part of a larger collective, an important phenomenon in terms of the ability to face challenges and social pressures. This feeling of capacity can strengthen individuals' autonomy by stimulating a sense of control and motivation over changes in their life (Stumbo et al., 2015). Promoting autonomy means increasing individuals' ability to comprehend and act on their own and in their social networks (Onocko et al., 2012). These networks include family networks, which comprise dimensions such as affection, autonomy, and mutual adaptation among members (Baptista, 2009).

These aspects of community relationships are associated with improved mental health and well-being (McColl et al., 2001), contributing to recovery from acute health problems and better lives for those affected by chronic health problems (Lee et al., 2016). For example, a survey showed that even when controlling for the effect of sociodemographic factors, a lower level of community integration has significant effects on depression in the elderly (Kim et al., 2016). Thus, this is an important factor in the recovery of individuals in various conditions, such as the elderly (Kim et al., 2016), the homeless (Chinchilla et al., 2019), and people with disabling diseases of a physical (Kashif et al., 2019) or psychiatric nature (Lee et al., 2016).

Similarly, social support has been linked to psychosocial factors that affect physical and mental health, protecting individuals from the negative effects of psychosocial stressors, curbing these effects, and/or increasing well-being (Cobb, 1976; Cohen et al., 2015; Cohen \& Wills, 1985). Social support-the material or affective resources that stem from the social networks to which the individual belongs-has been studied as a key factor of intervention in psychology, medicine, and social assistance. These resources may be affective (e.g., intimacy or esteem), instrumental (e.g., financial aids or services), or cognitive (e.g., counseling or information guides) (Gracia Fuster et al., 2002). The availability of a social support network and satisfaction with it have an impact on perceived health status and self-care behaviors (Gracia Fuster et al., 2002). In a study on the relationship between social support and health, based on 286 scientific articles published between 1980 and 2005 (Canesqui \& Barsaglini, 2012), links between social support and the following factors were found: (a) stress reduction as well as mental health, self-esteem, and psychological well-being issues; (b) the promotion and protection of health, quality of life, and disease prevention; (c) adaptation to chronic illnesses and loss as well as adherence to treatment and use of health services; (d) social integration, empowerment, reduction of social isolation, and increased feelings of control; and (e) reductions in morbidity and mortality.

Low community integration and poor social involvement lead to social isolation. This condition affects health, especially for groups that need greater social support, such as the elderly and people with chronic diseases (Nicholson, 2012). There is ample evidence that shows that social isolation results in negative health outcomes (Northcott et al., 2016). Nevertheless, few interventions have been developed to promote sociability and integration either at the family or the community level. Public health professionals can play a relevant role in addressing social isolation and may refer at-risk individuals to available community resources, potentially reducing the numerous negative health outcomes associated with this condition. Research has identified the development and strengthening of social networks, social assistance, and community integration as some of the factors to be considered in public health and social assistance policies (Cullen \& Solomon, 2013; Thoits, 2010; Umberson \& Montez, 2010). However, few studies have examined the impact of Brazilian social assistance programs on the social support and community integration of its beneficiaries. This study developed a sociodemographic profile of the beneficiary population, explored the social support and community integration of the individuals monitored by PAIF, and identified which factors are associated with these constructs.

\section{Method}

\section{Participants}

Initially, two of the 21 CRAS located in Porto Alegre and one of the two CRAS located in Esteio were not probabilistically selected. In each CRAS, individuals were randomly selected using their number in the Federal Government's Unique Registry for Social Programs (i.e., government registry to identify and gather information on low-income families for inclusion in social assistance and income redistribution programs). These individuals were informed about the research objectives and implications and then invited to participate in the study. If one of these individuals did not agree to participate, a new random selection was 
carried out and another person was invited to participate. The research sample included individuals of both sexes over 18 years of age, randomly selected from the list of families monitored by PAIF staff, who volunteered to participate.

The sample was planned to be probabilistic (stratified random sampling); however, due to low adherence, the required number of respondents was not reached. Therefore, despite the randomized sampling method adopted, the 201 respondents constituted a non-probability sample. Overall, 158 were from Porto Alegre (the capital of the state of Rio Grande do Sul) and 43 from Esteio (a metropolitan regional city in the same state). The sociodemographic characterization of the sample is presented in Table 1.

Table 1

Sociodemographic Profile of the Sample

\begin{tabular}{|c|c|c|c|}
\hline Characteristics & $n(\%)$ & $M$ & $S D$ \\
\hline \multicolumn{4}{|l|}{ Sex } \\
\hline Men & $25(12.4)$ & & \\
\hline Women & $176(87.6)$ & & \\
\hline Age (years) & & 46.00 & 16.37 \\
\hline \multicolumn{4}{|l|}{ Marital status } \\
\hline Single & $107(53.2)$ & & \\
\hline Married & $50(24.9)$ & & \\
\hline Divorced & $14(7.0)$ & & \\
\hline Widowed & $30(14.9)$ & & \\
\hline Years of education & & 5.47 & 3.17 \\
\hline \multicolumn{4}{|l|}{ Religious } \\
\hline Yes & $161(80.1)$ & & \\
\hline No & 40 (19.9) & & \\
\hline Number of residents & & 4.13 & 2.23 \\
\hline & & $\mathrm{R} \$ 822.65$ & $\mathrm{R} \$ 590.89$ \\
\hline Family income* & & US $\$ 246.97$ & US\$ 117.39 \\
\hline Length of involvement with PAIF (months) & & 61.85 & 63.36 \\
\hline \multicolumn{4}{|l|}{ Receives social financial benefits } \\
\hline Yes & $149(74.1)$ & & \\
\hline No & $52(25.9)$ & & \\
\hline \multicolumn{4}{|l|}{ Type of benefit) } \\
\hline Programa Bolsa Família & $133(89.3)$ & & \\
\hline Others & $16(10.7)$ & & \\
\hline \multirow{2}{*}{ Benefit value* } & & $\mathrm{R} \$ 274.93$ & $\mathrm{R} \$ 218.42$ \\
\hline & & US\$ 82.54 & US\$ 65.57 \\
\hline
\end{tabular}

Note. * Converted from the average dollar exchange rate in 2015 (US\$ 3.331); $n=201$.

\section{Instruments}

The instruments used were:

\section{Questionnaire of Sociodemographic Characteristics}

This questionnaire contained questions related to sex, age, marital status, level of education, profession/occupation, family income, living and cohabitation conditions, and history of participation in PAIF.

\section{Questionnaire of Community Social Support (Gracia Fuster et al., 2002)}

This instrument contains 25 items and is composed of the following scales: Community Integration, Community Participation, Informal Social Support, and Formal Social Support. Scale 1 is composed of five items - e.g., "I feel the neighborhood as my own"-which assess satisfaction with social relationships, while Scale 2 is composed of six items-e.g., "I participate in social activities in my neighborhood or community"- 
which evaluate engagement in community activities. Scale 3 is composed of ten items that refer to non-official organizations like community associations, neighborhood associations, the church, political or union groups, and NGOs - e.g., "I can find people who would help me solve my problems" and "I can't find understanding and support"-and which evaluate perceptions of community networks in informal systems. Scale 4 is composed of four items about official organizations and services, like social services, educational projects, and mental health centers-e.g., "These organizations and services are an important source of support" and "These services do not inspire trust"—which evaluate perceptions of community networks in formal systems. Participants were asked to rate the items using a five-point Likert scale, ranging from 1 Strongly disagree to 5 Strongly agree. Higher scores indicate a better perception of community support expressed in the dimensions of Community Integration, Community Participation, Informal Social Support, and Formal Social Support. The original instrument built in Spain presented the following reliability values (Cronbach's alpha coefficient): 0.88 for Community Integration, 0.86 for Community Participation, 0.85 for Informal Social Support, and 0.85 for Formal Social Support. Regarding validity, the instrument presented direct correlations with measures of social self-esteem and inverse correlations with measures of depressive symptomatology and feelings of loneliness. The average scores in Spain were 16.14 for Community Integration, 16.52 for Community Participation, 14.57 for Formal Social Support, and 32.20 for Informal Social Support. The instrument used was translated from Spanish into Brazilian Portuguese for the purposes of this study as part of a project to adapt the scale to the Brazilian context.

\section{Inventory of Family Support Perception - IPSF (Baptista, 2009; Baptista et al., 2009)}

This instrument consists of 42 statements with a three-point Likert-type response scale $(2=$ Always, $1=$ Sometimes, $0=$ Never). It evaluates the respondents' perceptions about family relationships in terms of affection, autonomy, and adaptation among members, divided into the following three factors: AffectionateConsistent with 21 items (e.g., "My family members touch and hug each other"), Family Adaptation with 13 items (e.g., "I feel like a stranger to my family"), and Family Autonomy with 8 items (e.g., "My family gives me as much freedom as I want"). The first factor evaluates the expression of affection among family members (e.g., a welcoming attitude, communication, respect, empathy), the second is composed of questions regarding negative feelings and behaviors towards the family (e.g., anger, isolation, exclusion, shame), and the third evaluates the reliability of relationships, freedom, and privacy among family members. The items in the second dimension (Family Adaptation) are reversed, so lower scores indicate more family support, which means more positive behavior toward the family (i.e., little or no anger, isolation, exclusion, etc.). Regarding reliability, Factor 1 had a Cronbach's alpha of 0.91, Factor 2 reached 0.90, and Factor 3 reached 0.78, while the overall scale in the original study reached 0.93 (Baptista, 2009), 0.91 for Factor 1, 0.84 for Factor 2, 0.77 for Factor 3, and 0.93 for the total sum of the inventory in an additional study (Baptista et al., 2009). The total score of the instrument, which can range from 0 to 84, is calculated by adding Factors 1 and 3 with the inverted scores of the second factor.

\section{Procedure}

Before answering the survey, participants expressed their agreement by signing an informed consent form. Their anonymity was guaranteed and only the researchers had access to their data, following ethical considerations detailed in National Health Council Resolution 510/2016 on human subject research. The project was submitted to and approved by the ethics committee of the Pontifícia Universidade Católica do Rio Grande do Sul and the Municipal Health Secretariat of Porto Alegre (Certificate of Presentation of Ethical Appreciation 12842113.5.3001.5338).

Data collection was carried out in 2015. Standardized questionnaires were individually administered by psychologists or psychology students. In addition, all members of the research team received training to administer the questionnaires. On average, 15 to 20 minutes were sufficient for respondents to complete the instrument. Data were directly collected at CRAS.

\section{Data Analysis}

The collected data were coded, digitized, stored, and analyzed with SPSS version 21 for Windows. Descriptive analyses were carried out first. Afterwards, Pearson or Spearman tests were performed to measure the association between community integration and family support, family autonomy, age, informal social support, the monetary value of the benefit received, and the length of use of PAIF. Variables that 
showed a direct association with community integration were included in a linear regression model using the stepwise method.

\section{Results}

Most PAIF users received some type of social financial benefit, with PBF being the most common one. Other benefits include the Child Labor Eradication Program, which aims to prevent children from being driven into work, Auxílio Brasil Carinhoso, which aims to strengthen the care of children up to 6 years of age, and Benefício de Prestação Continuada, which offers income to people with disabilities or the elderly without means of sustaining themselves, among others. Being equivalent to $33.4 \%$ of total family income, the sum provided plays a relevant role in the recipients' subsistence.

The average monthly per capita family income of the sample was R $\$ 199.19$ (US\$ 59.80; converted from the average dollar exchange rate in 2015-US\$3.331-), placing these families in the low socioeconomic class or stratum 3, "Vulnerable". Families placed in stratum 3 have a per capita income of up to $\mathrm{R} \$ 291$, according to the criteria adopted by the Brazilian government (Comissão para Definição da Classe Média no Brasil, 2012). This stratum represents $19 \%$ of the Brazilian population, placing it above two other strata: "Poor, although not extremely poor" and "Extremely poor". However, according to the criteria adopted by Mazzon and Kamakura (2013), called "Brazilian criteria", the sample can be classified as stratum 1, "Extremely poor", which comprises families that earn an average income of $\mathrm{R} \$ 854$, in contrast to the criteria adopted by the Brazilian government.

The average score for perceived family support was $54.99(S D=15.97)$, with possible scores ranging from 16 to 83, which represents a medium-low score. The highest scores were, in this order: Informal Social Support $(M=34.40, S D=10.24$, range $=10-50)$, Formal Social Support $(M=16.84, S D=3.34$ range $=4-20)$, Community Integration $(M=16.50, S D=5.42$, range $=5-25)$, and Community Participation $(M=15.39$, $S D=5.84$, range $=6-30)$.

The correlation analysis indicated a relationship between community integration and family support $(r=0.146, p<0.05)$, family autonomy $(r=0.140, p<0.05)$, age $(r=0.374, p<0.01)$, informal social support $(r=0.162, p<0.05)$, monetary value of the benefit received $(r=0.235, p<0.01)$, and the length of use of PAIF ( $r=0.145, p<0.05$ ). These variables were then included in the regression model through a stepwise method shown in Table 2. As this method eliminates variables that do not show an association, the following variables were excluded: informal social support, family support, length of use of PAIF, and family autonomy.

The model was significant and explained $30.5 \%$ of the variance of Community Integration, $F(4.144$, $200)=15.78, R^{2}=0.305, p<0.001$. The coefficients of standardized regression (B) indicated that age had the largest effect, with older respondents feeling more integrated. The monetary value of the benefit received by the family and Community Participation also contributed significantly to the model, with those who receive a larger sum and participate more feeling more integrated. The analysis of residuals and scatter plots revealed no inadequacy conditions in the results obtained.

Table 2

Linear Regression Model for Community Integration

\begin{tabular}{lcccccc}
\hline \multicolumn{1}{c}{ Model } & $B$ & $S E B$ & $B$ & $95 \%$ CI of $B$ & $t$ & $p$ \\
\hline Community integration (constant) & 2.232 & 1.922 & & & 1.161 & 0.247 \\
Age & 0.125 & 0.028 & 0.323 & {$[0.069,0.180]$} & 4.474 & $<0.001$ \\
Community participation & 0.219 & 0.068 & 0.234 & {$[0.085,0.353]$} & 3.224 & 0.002 \\
Benefit value (R\$) & 0.006 & 0.002 & 0.224 & {$[0.002,0.010]$} & 3.200 & 0.002 \\
\hline
\end{tabular}




\section{Discussion}

There is a clear predominance of women among the people monitored by PAIF (87.6\%). This figure is similar to those found in other studies with families receiving basic social assistance. A predominance of women beneficiaries may be associated with PBF. Although this policy does not formally predict a preference for women in income transfer, in practice, women are prioritized due to the understanding that women often manage family needs and use this benefit to feed their children (Instituto Brasileiro de Análises Sociais e Econômicas, 2008; Veras Soares \& Silva, 2010).

Considering that $75.5 \%$ of the sampled women were single, widowed, or divorced, this phenomenon can be hypothesized to derive from traditional gender roles, which help to explain the predominance of women among PAIF beneficiaries. Attention should be paid to the time spent using this service (5.15 years), which demonstrates a continuity of the service provided as well as a link with CRAS. The average schooling level of the respondents (5.47 years), however, was below the national average of 7.6 years (United Nations Development Programme, 2020).

According to the evaluation criteria of the IPSF (Baptista, 2009), the sample scored below the expected average (61.17) and can thus be classified in the medium-low category (54 to 63 points). In relation to the remaining constructs evaluated by the Questionnaire of Community Social Support (Gracia Fuster et al., 2002), the averages found in this study proved to be quite like those of Spain, without significant variations.

The results show that, while social support provided by the community network is within the average range, social support provided by the family network is below average. Family support is within the "mediumlow" category, one point away from being placed in the "low" category. A study on social support among PAIF users from the qualitative point of view of psychologists working in this service might help to explain these results (dos Santos-Lobo et al., 2015). Professionals have observed that the family network, in most cases, is fragile and marked by bond rupture. As a coping strategy, the person turns to the community in search of the social support that is not sufficiently ensured through the family. In the community, informal support networks composed of neighbors and formal support networks composed of professionals working in CRAS are equally important.

The linear regression model results indicate that older people tend to establish relationships and feel welcome in the community network, which strengthens their sense of belonging. This propensity of older people to be involved in the community may be related to the time of residence in the community, which was not evaluated in the present study. Still, it can be said that age is a predictor of greater integration into the community; in other words, as people get older in the community, their integration increases.

An association was also observed between Community Participation and the monetary value of the benefit received by the family. The majority of users receiving a benefit were part of PBF. This result may be linked to the goals of the PAIF service, which, by monitoring PBF beneficiaries, seeks to strengthen community bonds (SNAS, 2012). Although no specific studies were found on the relationship between social support or community integration and PBF, a vast amount of literature addresses the impact of $\mathrm{PBF}$ in multiple social spheres (Rego \& Pinzani, 2014). For instance, a study that considered 63 articles and reports on this topic (Mourão \& de Jesus, 2011) revealed the impact of PBF on access to public services for subjects in a variety of disadvantageous conditions.

Finally, it should be noted that the relationship found between Community Integration and Community Participation was expected in view of the closely associated constructs that make up social support. Indeed, community participation may be one of the factors that promote community integration. Individuals who engage in social group activities within their area of residence, whether in formal or informal support systems, tend to perceive greater integration with the community (Gracia Fuster et al., 2002). Thus, the more engaged individuals are in social activities, the more welcomed they will feel in the community and the greater their sense of belonging to the community will be. Although the correlation between the length of PAIF participation and community integration was weak, it indicates a trend toward higher levels of community integration in social benefit recipients. This suggests the need to study the requirements for participation in formal systems, as the requirements for entering PAIF ultimately promote integration with formal systems. To continue receiving the benefit, families must meet requirements such as prenatal care, child vaccination, school enrollment, and group activities in CRAS (SNAS, 2005). Thus, since compliance with these obligations is monitored, beneficiaries' contact with public health, educational services, and social assistance is encouraged (Mourão \& de Jesus, 2011). Furthermore, this results in the creation and expansion 
of links among the community through relationships with public service professionals and group activities offered by CRAS.

\section{Conclusions}

Although social support in the community network was found to be within the average range, social support provided by family networks was below average. These results may be understood with further studies on the fragility of the family networks of PAIF users and addressed by means of investments in community bonds, mainly through neighbors and PAIF professionals as a coping strategy.

Regarding the impact of the monetary value of the benefits received on community integration, one possible hypothesis is that it is due to the monitoring carried out by public agencies to ensure that families meet the requirements for PBF benefits. This explanation is further strengthened by the correlation found between the duration of PAIF use and community integration.

Lastly, it is necessary to point out the limitations of this study and offer some suggestions for future research. First, the sample was planned to be probabilistic, but low participant adherence made this impossible. Second, the Questionnaire of Community Social Support has not yet been validated or adapted for the Brazilian context. Nevertheless, this study pioneered the administration of this instrument to the Brazilian population. Future research should examine how the level of community integration varies between persons who participate in social programs and those who do not, as this can help to determine the role of predictor variables in different samples. In order to gain a clearer understanding of the relationship between social support and community integration among PAIF users, more studies should be conducted using larger sample sizes and populations in other regions of Brazil.

\section{References}

Baptista, M. N. (2009). Inventário de Percepção de Suporte Familiar - IPSF [Family Support Perception Inventory - IPSF]. Vetor.

Baptista, M. N., Teodoro, M. L. M., Cunha, R. V. D., Santana, P. R., \& Carneiro, A. M. (2009). Evidência de validade entre o Inventário de Percepção de Suporte Familiar-IPSF e Familiograma-FG [Evidence of validity between the Family Support Perception Inventory-IPSF and Familiogram-FG]. Psicologia: Reflexão e Crítica, 22(3), 466-473. https://doi.org/10.1590/S0102-79722009000300018

Caixa Econômica Federal. (n.d.). Perguntas frequentes sobre o Programa Bolsa Família [Frequently asked questions about the Bolsa Família Program]. Governo do Brazil, Secretaria Especial da Fazenda. Retrieved September 29, 2016, from http://www.caixa.gov.br/programas-sociais/bolsa-familia/perguntas-frequentes/Paginas/default.aspx

Canesqui, A. M., \& Barsaglini, R. A. (2012). Apoio social e saúde: pontos de vista das ciências sociais e humanas [Social support and health: Points of view of social sciences and humanities]. Ciência \& Saúde Coletiva, 17(5), 1103-1114. https://doi.org/10.1590/S141381232012000500002

Chinchilla, M., Gabrielian, S., Hellemann, G., Glasmeier, A., \& Green, M. (2019). Determinants of community integration among formerly homeless veterans who received supportive housing. Frontiers in Psychiatry, 10, Article 472. https://doi.org/10.3389/fpsyt.2019.00472

Cobb, S. (1976). Social support as a moderator of life stress. Psychosomatic Medicine, 38(5), 300-314. https://doi.org/10.1097/00006842197609000-00003

Cohen, S., Janicki-Deverts, D., Turner, R. B., \& Doyle, W. J. (2015). Does hugging provide stress-buffering social support? A study of susceptibility to upper respiratory infection and illness. Psychological Science, 26(2), 135-147. https://doi.org/10.1177/0956797614559284

Cohen, S., \& Wills, T. A. (1985). Stress, social support, and the buffering hypothesis. Psychological Bulletin, 98(2), 310-357. https://doi.org/10.1037/0033-2909.98.2.310

Comissão para Definição da Classe Média no Brasil. (2012). Relatório de definição da classe média no Brasil [Report defining the middle class in Brazil]. Brasil, Presidencia da Republica, Secretaria de Assuntos Estratégicos. https://es.slideshare.net/saepr/relatrio-paradefinio-da-classe-mdia-no-brasil

Cullen, S. W., \& Solomon, P. L. (2013). Family community integration and maternal mental health. Administration and Policy in Mental Health Services Research, 40(2), 133-144. https://doi.org/10.1007/s10488-011-0386-4

Departamento de Proteção Social Básica. (2017). Concepção de convivência e fortalecimento de vínculos [Conception of coexistence and strengthening of bonds]. Brasil, Ministério do Desenvolvimento Social, Secretaria Nacional de Assistência Social. http://www.mds.gov.br/webarquivos/publicacao/assistencia_social/Cadernos/concepcao_fortalecimento_vinculos.pdf

dos Santos-Lobo, N., Motta, R. F., Cargnelutti, E. S., \& Pizzinato, A. (2015). A percepção dos(as) trabalhadores(as) sobre o apoio sóciofamiliar no contexto da assistência social brasileira [The workers' perception of social and family support in the context of Brazilian social assistance]. In M. Martino (Coord), I Coloquio Regional ¿̇Familias Contemporáneas - Intervenciones Contemporáneas?: Familias y Nueva Matriz de Protección Social [I Regional Colloquium: Contemporary Families - Contemporary Interventions: Families and the New Social Protection Matrix] (pp. 520-532). Universidad de la República, Departamento de Trabajo Social. https://www.adasu.org/prod/2/728/Documento.de.Trabajo..pdf

Gracia Fuster, E., Herrero Olaizola, J., \& Musitu Ochoa, G. (2002). Evaluación de recursos y estresores psicosociales en la comunidad. Síntesis.

Instituto Brasileiro de Análises Sociais e Econômicas. (2008). Repercussões do Programa Bolsa Família na segurança alimentar e nutricional das famílias beneficiadas: documento sintese [Repercussions of the Bolsa Familia Program on the food and nutritional security of the families benefited: Summary document]. http://www.ibase.br/userimages/ibase bf sintese site.pdf

Jaccoud, L., Hadjab, P. D. E. -M., \& Chaibub, J. R. (2010). The consolidation of social assistance in Brazil and its challenges, 1988-2008 (Working Paper N ${ }^{\circ}$ 76). International Policy Centre for Inclusive Growth. https://ideas.repec.org/p/ipc/wpaper/76.html 
Janczura, R. (2012). Risco ou vulnerabilidade social? [Social risk or vulnerability?]. Textos \& Contextos (Porto Alegre), 11(2), 301-308. https://www.redalyc.org/articulo.oa?id=321527332009

Kashif, M., Jones, S., Darain, H., Iram, H., Raqib, A., \& Butt A. A. (2019). Factors influencing the community integration of patients following traumatic spinal cord injury: A systematic review. Journal of the Pakistan Medical Association, 69(9),1336-1342. https://pubmed.ncbi.nlm.nih.gov/31511721/

Kim, H. O., Choi, Y. S., Lee, J. H., Seo, A. R., \& Park, K. S. (2016). The association between hopelessness, social support and community integration and depression among elderly living alone. Journal of Agricultural Medicine and Community Health, 41(4), 195-204. https://doi.org/10.5393/JAMCH.2016.41.4.195

Lee, O. E. -K., Pantas, S., \& Coyle, C. (2016). Chorus for community integration and recovery for men with psychiatric disabilities in a supportive housing community. Smith College Studies in Social Work, 86(3), 240-257. https://doi.org/10.1080/00377317.2016.1191813

Mazzon, J. A. \& Kamakura, W. (2013). Estratificação socioeconômica e consumo no Brasil [Socioeconomic stratification and consumption in Brazil]. Blucher.

McColl, M. A., Davies, D., Carlson, P., Johnston, J., \& Minnes, P. (2001). The community integration measure: Development and preliminary validation. Archives of Physical Medicine and Rehabilitation, 82(4), 429-434. https://doi.org/10.1053/apmr.2001.22195

Mourão, L., \& de Jesus, A. M. (2011). Bolsa Família (Family Grant) Programme: An analysis of Brazilian income transfer programme. Field Actions Science Reports, Special Issue 3, 3-7. https://www.scopus.com/inward/record.url?eid=2-s2.084880579510\&partnerID=40\&md5=a4d4baf608facdb6285a0631827c9a04

Nicholson, N. R. (2012). A review of social isolation: An important but underassessed condition in older adults. The Journal of Primary Prevention, 33(2-3), 137-152. https://doi.org/10.1007/s10935-012-0271-2

Northcott, S., Moss, B., Harrison, K., \& Hilari, K. (2016). A systematic review of the impact of stroke on social support and social networks: Associated factors and patterns of change. Clinical Rehabilitation, 30(8), 811-831. https://doi.org/10.1177/0269215515602136

Onocko Campos, R. T., \& Campos, G. W. de S. (2012). Co-construção de autonomia: o sujeito em questão [Co-construction of autonomy: The subject in question]. In G. W. S. Campos, J. R. A. Bonfim, M. C. S. Minayo, M. Akerman, M. Drumond Júnior \& Y. M. de Carvalho (Orgs.), Tratado de saúde coletiva [Collective health treaty] (2nd ed., pp. 669-688). Hucitec.

Rasella, D., Aquino, R., Santos, C. A. T., Paes-Sousa, R., \& Barreto, M. L. (2013). Effect of a conditional cash transfer programme on childhood mortality: A nationwide analysis of Brazilian municipalities. The Lancet, 382(9886), 57-64. https://doi.org/10.1016/S0140-6736(13)60715-1

Rego, W. L., \& Pinzani, A. (2014). Vozes do Bolsa Família: autonomia, dinheiro e cidadania [Voices of Bolsa Família: Autonomy, money and citizenship] (2 $2^{\text {nd }}$ ed.). Unesp.

Secretaria Nacional de Assistência Social. (2005). Política nacional de assistência social - PNAS/2004: norma operacional básica - NOB/SUAS [National policy of social assistance - PNAS/2004: Basic operational norm - NOB/SUAS]. Brasil, Ministério do Desenvolvimento Social e Combate à Fome. https://www.mds.gov.br/webarquivos/publicacao/assistencia_social/Normativas/PNAS2004.pdf

Secretaria Nacional de Assistência Social. (2012). Orientações técnicas sobre o PAIF (Vol. 2): trabalho social com famílias do serviço de proteção e atendimento integral à família [Technical guidelines on the PAIF (Vol. 2): Social work with families in the service of protection and comprehensive care to the family]. Brasil, Ministério do Desenvolvimento Social e Combate à Fome. http://www.mds.gov.br/webarquivos/publicacao/assistencia_social/Cadernos/Orientacoes_PAIF_2.pdf

Secretaria Nacional de Assistência Social. (2016). Censo SUAS 2015: resultados nacionais, centros de referência da assistência social, CRAS. Brasil, Ministério do Desenvolvimento Social e Combate à Fome. http://aplicacoes.mds.gov.br/snas/vigilancia/index2.php

Soares, F. V., \& Silva, E. (2010). Conditional cash transfer programmes and gender vulnerabilities in Latin: Case studies from Brazil, Chile and Colombia. Overseas Development Institute.

Stumbo, N. J., Wilder, A., Zahl, M., DeVries, D., Pegg, S., Greenwood, J., \& Ross, J. -E. (2015). Community integration: Showcasing the evidence for therapeutic recreation services. Therapeutic Recreation Journal, 49(1), 35-60. https://js.sagamorepub.com/tri/article/view/5913

Thoits, P. A. (2010). Stress and health: Major findings and policy implications. Journal of Health and Social Behavior, 51(1_ suppl), S41S53. https://doi.org/10.1177/0022146510383499

Umberson, D., \& Montez, J. K. (2010). Social relationships and health: A flashpoint for health policy. Journal of Health and Social Behavior, 51(1_ suppl), S54-S66. https://doi.org/10.1177/0022146510383501

United Nations Development Programme. (2020). Human Development Report 2020 - Brazil. http://www.hdr.undp.org/sites/all/themes/hdr_theme/countrynotes/BRA.pdf

Veras Soares, F., \& Silva, E. (2010). Conditional cash transfer programmes and gender vulnerabilities in Latin America: Case studies from Brazil, Chile and Colombia. Overseas Development Institute.

Fecha de recepción: Enero de 2019.

Fecha de aceptación: Junio de 2020. 